\title{
SLC6A3 wt Allele
}

National Cancer Institute

\section{Source}

National Cancer Institute. SLC6A3 wt Allele. NCI Thesaurus. Code C113527.

Human SLC6A3 wild-type allele is located in the vicinity of 5p15.3 and is approximately 53 $\mathrm{kb}$ in length. This allele, which encodes sodium-dependent dopamine transporter protein, is involved in sodium-dependent internalization of dopamine. Mutation of the gene is associated with infantile Parkinsonism-dystonia. 